\begin{tabular}{cc|c}
\hline Tar. Bil. Der. & Journal of Agricultural Sciences \\
& $\begin{array}{c}\text { Dergi web sayfası: } \\
\text { www.agri.ankara.edu.tr/dergi }\end{array}$ & Journal homepage: \\
& www.agri.ankara.edu.tr/journal
\end{tabular}

\title{
Reducing the Air Temperature Inside the Simple Structure Greenhouse Using Roof Angle Variation
}

\author{
Krit TASHOO $^{\mathrm{a}}$, Sirichai THEPA ${ }^{\mathrm{a}}$, Ratanachai PAIRINTRA ${ }^{\mathrm{b}}$, Pichai NAMPRAKAI ${ }^{\mathrm{a}}$ \\ ${ }^{a}$ King Mongkut's University of Technology Thonburi, School of Energy, Environment and Materials, 126 Bangkok, 10140 ,THAILAND \\ ${ }^{\boldsymbol{b}}$ King Mongkut's University of Technology Thonburi, School of Bioresources and Technology, 126 Bangkok, 10140 ,THAILAND
}

\section{ARTICLE INFO}

Research Article

DOI: 10.1501/Tarimbil 0000001274

Corresponding Author: Sirichai THEPA, E-mail: sirichai.the@kmutt.ac.th, Tel: +66 (0) 817910308

Received: 19 August 2013, Received in Revised Form: 19 November 2013, Accepted: 24 November 2013

\begin{abstract}
There is a problem with the natural ventilation of a Simple Structure Greenhouse (SSG), having a roof with a gable end and a roof vent placed at a height of $<2.5 \mathrm{~m}$ above the greenhouse column, with an average roof angle of $<15^{\circ}$, that causes the air temperature inside the greenhouse to be much higher than the ambient temperature (an average of 6-8 K), which can be found in greenhouses that are covered by plastic film. This investigation considers the flow pattern and temperature distribution in an empty greenhouse with a dimension of $48 \mathrm{~m}^{2}$ by using the computational fluid dynamic technique, CFD, as a tool for the study. It was found that the heat convection generated wake flows under the canopy by thermally driven ventilation, and that the heat was transferred from the moving air into the greenhouse by convection and was allowed through the hot temperature outlet via the sidewall vents by the wind. The change of the various roof angles at an average angle of $15^{\circ}, 30^{\circ}$ and $42^{\circ}$ pitch, in combination with an external wind speed of $<2.0 \mathrm{~m} \mathrm{~s}^{-1}$, serves the purpose of reducing the temperature inside the greenhouse to approximately ambient air temperature, considering the loads of external wind speed applied to the roof. The investigation results of the ventilation rate and the wind pressure coefficient, at a reference roof angle of $30^{\circ}$, is adequate for greenhouse construction. There will be air ventilation, called mixed convection, inside the greenhouse where the $G r R^{-2}<1$ and temperature differences $\left(\mathrm{T}_{\mathrm{i}}-\mathrm{T}_{\mathrm{o}}\right)$ at $2.5 \mathrm{~m}$ above ground are less than $2 \mathrm{~K}$.

Keywords: Simple greenhouse; Air ventilation; Computational fluid dynamics; Roof pitch; Variation in roof angle

\section{Basit Yapılı Serada Çatı Açısı Değişimini Kullanarak Sera İç Hava Sıcaklığının Azaltılması}

\section{ESER BİLGISİ}

Araştırma Makalesi

Sorumlu Yazar: Sirichai THEPA, E-posta: sirichai.the@kmutt.ac.th, Tel: +66 (0) 817910308

Geliş Tarihi: 19 Ağustos 2013, Düzeltmelerin Gelişi: 19 Kasım 2013, Kabul: 24 Kasım 2013

\section{ÖZET}

Sera iç sıcaklığının çevre sıcaklığından 6-8 K daha yüksek olması; ortalama çatı açısının $15^{\circ}$ den küçük, havalandırmasının sera tabanından yüksekliği $2.5 \mathrm{~m}$ den az ve üçgen çatıya sahip olan doğal havalandırmalı plastik örtüyle kaplı basit yapılı 
seralarda seralarda bir sorun olarak karşımıza çıkmaktadır. Bu araştırmada akışkan dinamiği tekniğini (CFD) kullanarak $48 \mathrm{~m}^{2}$ büyüklüğündeki boş bir serada akış paterni ve sıcaklık dağılımı incelenmiştir. Meydana gelen ısı gölgeliğin altında akışın meydana gelmesine neden olur ve 1sı hareketli havadan sera içine konveksiyonla iletilir. Bu 1sı, rüzgarla yan duvarlardaki açıklıktan dışarı atılır. Ortalama $15^{\circ}, 30^{\circ}$ ve $42^{\circ}$ çatı eğimlerinde, $2 \mathrm{~m} \mathrm{~s}^{-1}$ rüzgar hızı kombinasyonunda ve dış rüzgar yükünün çatıya etki ettiği varsayımında seradaki hava sıcaklığının dış hava sıcaklığından daha düşük olduğu belirlenmiştir. Çatı açısının $30^{\circ}$ olduğu koşulda havalandırma ve rüzgar basınç katsayısının en uygun olduğu sonucuna varılmıştır. $G r R^{-2}<1$ ve yerden $2.5 \mathrm{~m}$ yukarıda sıcaklık farkının $\left(\mathrm{T}_{\mathrm{i}}-\mathrm{T}_{\mathrm{o}}\right) 2 \mathrm{~K}$ den daha az olduğu durumda karışık iletim diye adlandırılan hava ventilasyonunun olabileceği sonucuna varılmıştır.

Anahtar Kelimeler: Basit sera; Hava ventilasyonu; Hesaplamalı akışkanlar dinamiği; Çatı eğimi; Çatı açısı değişimi

(C) Ankara Üniversitesi Ziraat Fakültesi

\section{Introduction}

$75 \%$ of the agriculturists in Northern Thailand have a low income. Rain storms and some species of insects have resulted in greenhouses, most of which have the characteristics shown in Figure 1, being widely used in several areas. However, the use of greenhouses has introduced another problem, due to the accumulated heat within the greenhouses during daytime and after rain. A simple way of reducing the hot air in the greenhouses is natural ventilation, because it is economical. Tuntiwaranuruk et al (2006) studied the air temperature in a greenhouse used in the Royal Project Foundation and found that the difference in temperature between the inside and the outside is 6-8 K, depending on the ambient temperature. Dayığlu (2009) developed mathematical model to define heat and mass transfer processes by microclimatologic methods in the greenhouse crops. The crop structure was depicted by means of plant architectural parameters and distribution functions. The energy and mass balances were identified for a differential stratum of the plant stand. The model contained the processes such as the solar radiation fractions (total, PAR and NIR), net radiation; water vapor and $\mathrm{CO} 2$ transfer for different levels of plant stand. Sethi (2009) studied the rise of the inside air temperature and the orientation of the five most commonly used single-span shapes of greenhouses, namely even-span, uneven-span, vinery, modified arch and Quonset types. The results show that the inside air temperature of an unevenspan shaped greenhouse is $4.6 \mathrm{~K}$ (maximum) and that of a Quonset shaped greenhouse is $3.5 \mathrm{~K}$ (daily average) at an orientation of $31^{\circ} \mathrm{N}$ latitude. Krasaechai (1999) found that the side column height should be between 3-4 m, in order to reduce the stored heat under the roof. A commercial, Parral type greenhouse has a gutter height of $3.6 \mathrm{~m}$, and an internal air temperature difference in greenhouses of over $9 \mathrm{~K}$ (Baezaa et al 2009). This method cannot be applied to the greenhouse type SSG, because the height of the column influences the structure of the high ridge and can be damaged by windstorms. Therefore, ventilation for the purpose of reducing air temperature can be done by opening the side wall. This method results in the loss of humidity in leaves and blast wind, affecting the carbon dioxide absorption performance of the plant. Kittas et al (1997) studies, based on a mathematical model to calculate the optimal sidewall vents, found that the optimal size of sidewall vents is $15-25 \%$ of the greenhouse floor area. This would provide enough ventilation in the Mediterranean region. Connellan (2000) reported that, in a naturally ventilated greenhouse, the minimum ventilation of the opening area should be $20 \%$ of the greenhouse floor area. This should be maintained in order for the greenhouse temperature to be nearer to the external, ambient temperature. Albright (2002) found that the inside temperature in the greenhouse is close to the ambient temperature when the ridge and side opening areas are more than $10 \%$ of the greenhouse area.

Many researchers have studied the cooling technology in agricultural greenhouses, such as roof and side opening greenhouses and porous screen 


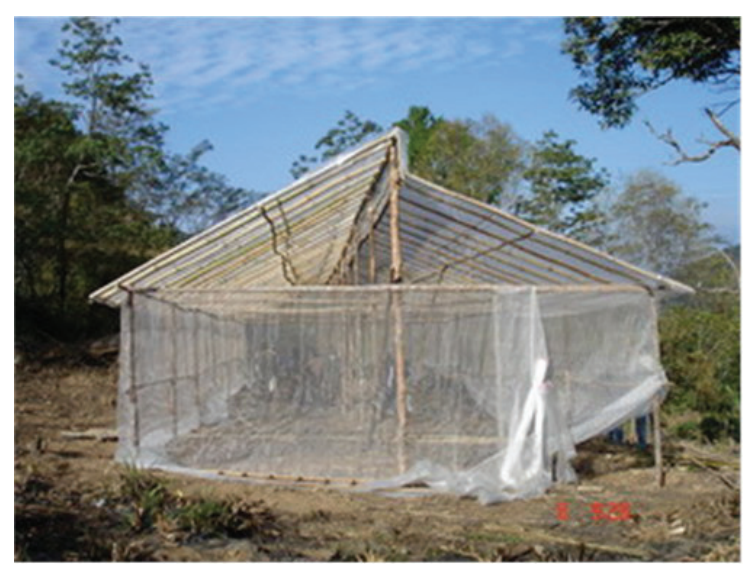

(a)

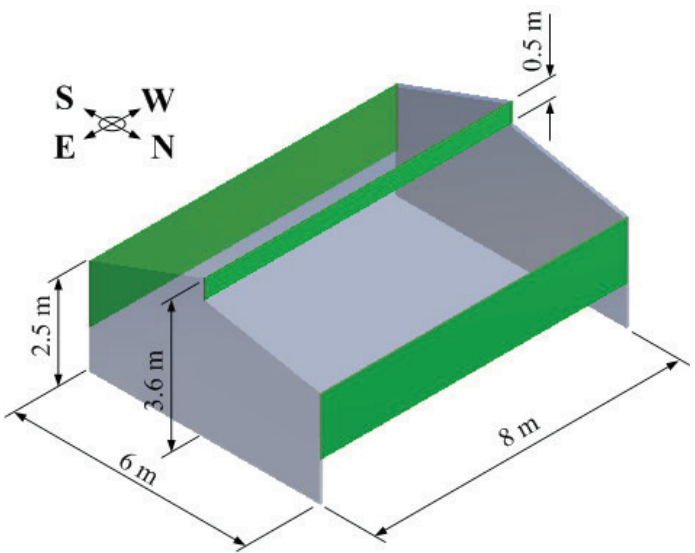

(b)

Figure 1-Prototype of a simple structure greenhouse (SSG) built with a bamboo structure (a) and a schematic view of the empty SSG with measurements of the various openings (b)

Şekil 1-Basit yapılı seranın ilk örneği: a, bamboo yapı; b, ölçüm aralıkları

greenhouses (Sethi \& Sharma 2007). However, little research has been done on cooling the greenhouse by using a ceiling heat storage technique by means of varying the angles of the roofs. This research focuses on the SSG-type of greenhouse. The side wall and roof opening may not be sufficient for ventilation. Thus, the variation of the roof angle may prove to be a new method that can reduce the heat load over the centre of the greenhouse, without increasing the height of the column. Baezaa et al (2009) performed simulations of ventilation in Parral style greenhouses by a CFD technique validation of 2-D scale models of tunnel greenhouse. The vertical air temperature in the centre of the scale model greenhouses showed that the hot air rises to the ceiling of the greenhouses. Brugger et al (2005) studied the case of Parral style greenhouses by investigating only the outside wind speed of $>2 \mathrm{~m} \mathrm{~s}^{-1}$, using the Computational Fluid Dynamics technique, and found that a roof incline that is higher than $27^{\circ}$ does not reduce the ventilation rate inside greenhouse, but rather increases it. In case of the outside wind has an average speed of $<2 \mathrm{~m} \mathrm{~s}^{-1}$ (such as Thailand etc.), which often causes the ventilation system in the greenhouse to be mixed convection. $50 \%$ of the ventilation system in the greenhouse is generated by thermal driven ventilation as free convection, which affects the heat storage under the roof. Therefore, when the roofs incline increases and the length of the column decreases, this makes a decrease in the internal temperature of the greenhouse possible.

This paper studies natural ventilation for air temperature reduction in a simple structure greenhouse with a gable roof and a roof vent at a column height of $<3 \mathrm{~m}$, by using the CFD technique. Flow patterns and temperature distribution for various roof angles were investigated in order to determine the optimal roof pitch. The roof pitch that impacts on the outside structure of the greenhouse is studied by analysing the ventilation performance when wind pressure is applied to the roof. The study results will be used to define the roof pitch configuration for greenhouse construction design.

\section{Material and Methods}

\subsection{Ventilation systems}

Discussing the ventilation system in greenhouses on the basis of free convection implies that, even with forced convection, the temperature gradients in the fluid may give rise to free convection. Therefore, 
it is useful to have some criteria for the relative importance of free convection in forced convection. This has been defined by the following parameters:

$$
\frac{G r}{\operatorname{Re}^{2}}=\frac{\beta \Delta T g h}{u^{2}}
$$

This is a measurement of the relative importance of free convection in relation to forced convection. If $\mathrm{Gr} \operatorname{Re}^{-2}<1$, the ventilation system is considered to be primarily forced convection (wind driven ventilation). If the $G r R e^{-2}>1$, then free convection is dominant (thermal driven ventilation), whereas if the $G r \operatorname{Re}^{-2} \cong 1$, the ventilation system is considered to be mixed convection (Mills 1999).

In Equation $1, b$ is the volume coefficient of thermal expansion, $\Delta T$ is the internal and external air temperatures differences $(\mathrm{K}), g$ is the gravitation acceleration $\left(\mathrm{m} \mathrm{s}^{-1}\right), h$ is the vertical distance between the midpoints of the sidewall vent and roof vent $(\mathrm{m})$ and $u$ is the external wind speed $\left(\mathrm{m} \mathrm{s}^{-1}\right)$.

\subsection{Ventilation performance}

Natural ventilation is generated by two physical phenomena, known as stack and wind effects. Thus, methods for calculating ventilation referring to stack and wind effects have been proposed by Kittas et al (1997). The airflow exits through the greenhouse sidewall vents or roof vent, as defined by the following equation:

$$
Q=C_{d}\left[\left(\frac{A_{R} A_{S}}{\sqrt{A_{R}^{2}+A_{S}^{2}}}\right)^{2}\left(2 g \frac{\Delta T}{\bar{T}} h\right)+\left(\frac{A_{T}}{2}\right)^{2} C_{W} u^{2}\right]^{0.5}
$$

Where; $Q$ is the ventilation rate $\left(\mathrm{m}^{3} \mathrm{~s}^{-1}\right), A_{R}$ and $A_{S}$ are the areas of the roof and sidewall ventilation $\left(\mathrm{m}^{2}\right), A_{T}$ is total area of vents $\left(\mathrm{m}^{2}\right)$, respectively, and $C_{d}$ is the discharge coefficient of the ventilation opening. $\bar{T}$ is the absolute temperature $(\mathrm{K}), C_{w}$ is the global wind pressure coefficient and $u$ is the wind speed $\left(\mathrm{m} \mathrm{s}^{-1}\right)$.

In cases of wind driven ventilation where the stack effect is negligible, Equation 2 can be expressed by the following equation:

$$
Q=\frac{A_{T}}{2} C_{d} \sqrt{C_{W}} u
$$

In order to compare ventilation results obtained in the different greenhouses, modifying the nondimensional parameter of ventilation function, $G$ $(\alpha)$, as proposed by Bot (1983) has been used by a number of authors (Boulard \& Baille 1995; Pérez Parra et al 2004).

$G(\alpha)=\frac{Q}{u A}$

where; $A$ is the area of the ventilation opening in the greenhouse surface $\left(\mathrm{m}^{2}\right)$ and $Q$ is air ventilation output $\left(\mathrm{m}^{3} \mathrm{~s}^{-1}\right)$, as shown in Equations 2 and 3.

\subsection{Wind pressure coefficient}

Wind loads on the greenhouse cover are the result of external and internal pressures induced by the external wind on the cover. The aerodynamic or pressure coefficient, $C_{p}$, describes the corresponding pressure distribution on the external or the internal surfaces of a greenhouse, normalised by the dynamic wind pressure:

$C_{P}=\frac{P_{G}-P_{r e f}}{0.5 \rho u_{r e f}^{2}}$

Where; $P_{G}$ is the pressure on the greenhouse roof $(\mathrm{Pa}), P_{\text {ref }}$ is the pressure reference $(\mathrm{Pa}), u_{\text {ref }}$ is the wind velocity at a reference height $\left(\mathrm{m} \mathrm{s}^{-1}\right)$ and $r$ is the air density $\left(\mathrm{kg} \mathrm{m}^{-3}\right)$.

\subsection{Simple structure greenhouses in Thailand}

The SSG is constructed using materials available in the local area, such as wood and bamboo, which have a useful life of a few years depending on the treatment process. The greenhouse is constructed by simply fastening screws or tightening joints with a rope, for ease of repair or removal. If columns are formed by grouting cement into the soil at a height of $2.5 \mathrm{~m}$, then the greenhouse roof structure will be gabled. Because of the gable roof structure's impact on temperature and heat storage under the roof, a solution to the heat storage problem is to design the roof configuration with the gable-end vent at a height of $0.5 \mathrm{~m}$ and to cover the greenhouse roof with PVC film (Krasaechai 1999), with gable roof angles of $15^{\circ}-20^{\circ}$ depending on the greenhouse span and the 
length of the bamboo trunk. The average SSG size was found to be $24 \mathrm{~m}^{2}$.

\subsection{Problem definition}

An SSG with a width of $6 \mathrm{~m}$ and a depth of $8 \mathrm{~m}$ was constructed on the ground, without impeding the air flow, as shown in Figure 1b. The greenhouse height from ground level to the top of the gable roof is 3.6 $\mathrm{m}$ and the column or sidewalls are $2.5 \mathrm{~m}$ in height. The greenhouse is placed perpendicular to the north-south direction and across the wind direction. The sidewall and roof of the greenhouse are placed at an east-west direction and are covered by PVC film, while another side is allowed air ventilation at a point $0.4 \mathrm{~m}$ from the ground or at $15 \%$ of the sidewall's height (Kittas et al 1997). The size of the gable vents is $0.5 \mathrm{~m} \times 8 \mathrm{~m}$. Thus, the total area of the ventilation opening is $22 \%$ of the greenhouse floor area (Connellan 2000; Albright 2002) and the variations in the angles of the roof are given by an average of $15^{\circ}, 30^{\circ}$ and $42^{\circ}$. The geometry of the angle of the roofs is shown in Figure 2a-2c.

\subsection{Data records and measurements}

Research comparing simulation results to the information included in a measurement database was conducted by Tuntiwaranruk et al (2006), who studied SSG greenhouses. In Figure 3, the air temperature inside the greenhouse was measured by four thermistor probe temperature sensors (XTI10839+122, StowAway ${ }^{\mathrm{TM}}$ XTI Temperature Data Logger), placed in the middle of the greenhouse at a height of $0.9 \mathrm{~m}, 1.5 \mathrm{~m}, 2.0 \mathrm{~m}$ and $2.50 \mathrm{~m}$ from the ground. The solar radiation pyranometer (Kipp \& Zonen-CM3) was placed $1.5 \mathrm{~m}$ from the ground. The air temperature, wind speed and global solar radiation outside the greenhouse were measured by placing a sensor $6 \mathrm{~m}$ from the ground and $10 \mathrm{~m}$ away from the north-facing greenhouse sidewall. These were measured by the HOBO Weather Station Temperature Smart Sensor, the HOBO Wind Speed Smart Sensor and the CM11 pyranometer. The interior and exterior surface temperatures of the walls, roofs and the ground were measured by 26 thermocouples (Type-K), four for the roof surfaces, four for the wall surfaces and two for the ground surface. These thermocouples were connected to Campbell data loggers. Air ventilation is investigated by using an air velocity transmitter (HVAC, EE65, Elektronik, Engerwitzdorf, Austria) according to the ASHRAE standard (2001), by placing 25 points parallel to the length of the sidewall vents and at the gable vent (ASHRAE 1981). The average measurement data for analysis was selected based on the ambient air temperature $305-306 \mathrm{~K}$ and the global solar radiation of $700-800 \mathrm{~W} \mathrm{~m}^{-2}$. This value is based on the weather data of Thailand.

\subsection{Computational fluid dynamic method}

Considering that the air in steady flow conditions consists of continuity equations in terms of mass conservation, the Navier-Stokes momentum equations are considered together with gravity body force and energy equations that have physical air properties related to considering the air flow inside the computational domain. All the abovementioned were used for modeling the airflow in the computational domain by means of the ANSYS CFX software package (ANSYS, Inc., Canonsburg, Pennsylvania, USA).

In this ventilation prediction, the viscosity was included, as well as being thermally driven to be a reference for the ambient temperature in terms of Boussinesq's approximation with a standard $\mathrm{k}$-epsilon (turbulent kinetic energy and dissipation rate) model representing turbulent transport inside the greenhouse (Mistriotis \& Briassoulis 2002; Ayata 2009). To generate accurate results, a secondorder, upwind discretisation scheme should be used for momentum, combined with heat and turbulence transport equations. The convergence criterion for all variables was $1 \times 10^{-4}$.

\subsection{Computational meshes}

The CFD simulations of the research used a general three-dimensional model and a system of equations built with variables numerically solved by the finite volume method. The computational mesh is closely modeled, with the experimental configuration (Figure 1b) based on unstructured mesh (Figure 


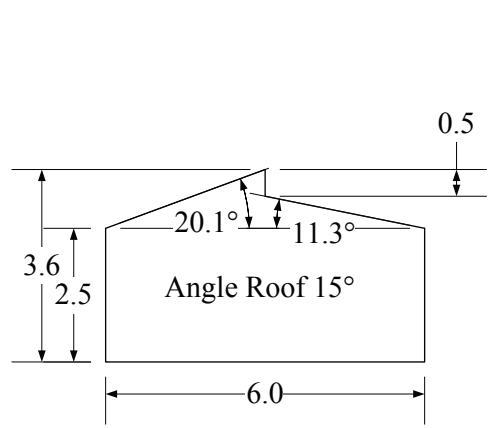

(a)

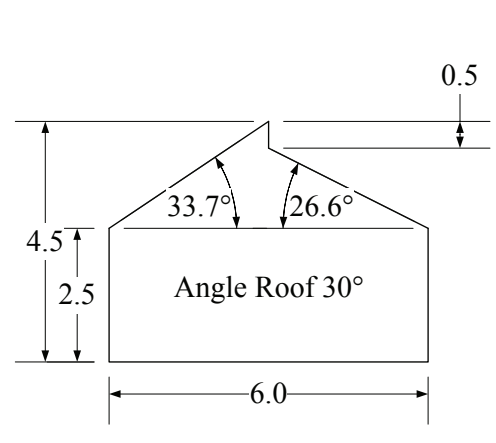

(b)

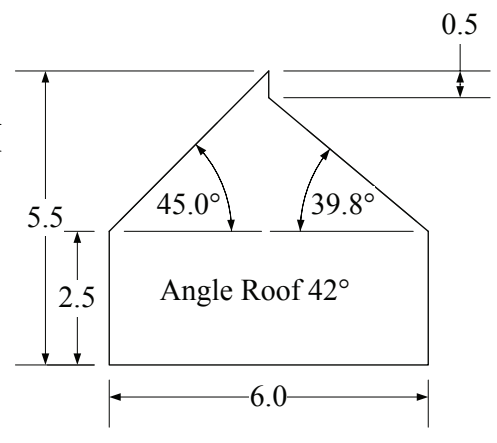

(c)

Figure 2-Greenhouse configurations with various roof angles. (a) $15^{\circ}$ average roof angle, (b) $30^{\circ}$ average roof angle, (c) $42^{\circ}$ average roof angle

Şekil 2-Farklı çatı açılarında sera düzenlemeleri: a, ortalama çatı açısı 15; b, ortalama çatı açısı $30^{\circ}$; c, ortalama çatı açısı $42^{\circ}$

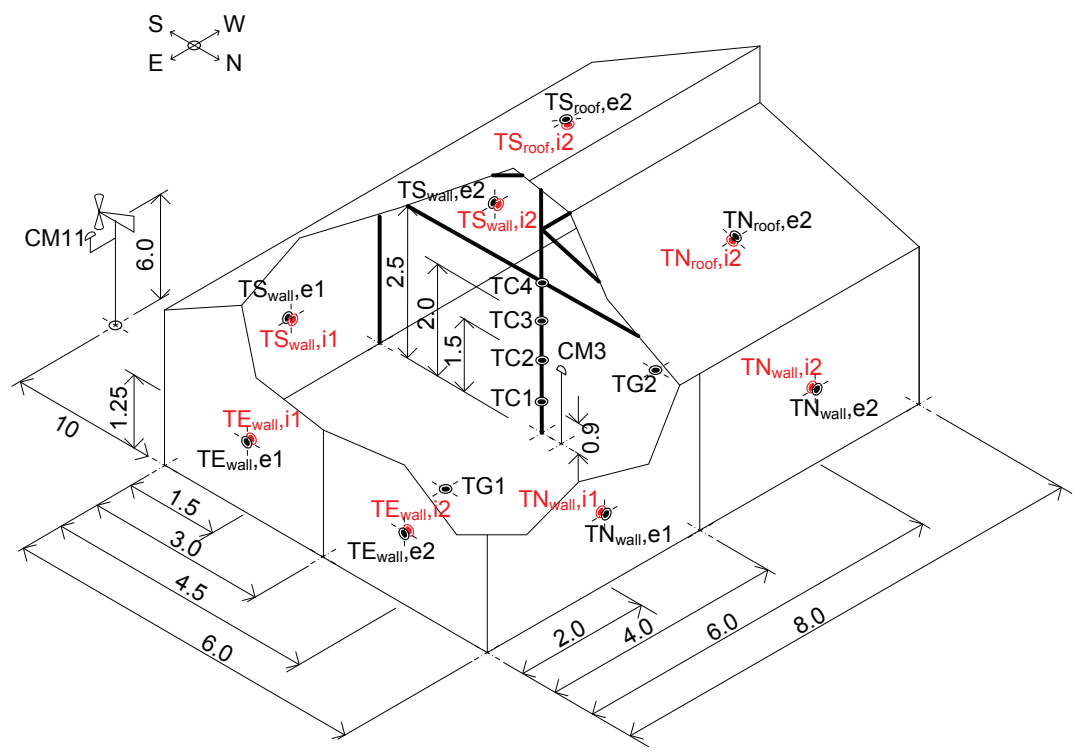

Figure 3-Positions of the measurement of temperatures, wind and radiation. Dimensions are in $\mathbf{m}$

Şekil 3-Sicaklık, rüzgar ve radyasyon ölçüm noktaları olup boyutlar m'dir

4a). The surrounding domain of the greenhouse was extended to prevent blockage effects (Figure 4b) (Burnett et al 2005; Richards \& Hoxey 1992). It has been verified that the domain extension does not significantly improve the accuracy of the simulations, but substantially increases the computing time and memory requirements. To obtain accuracy of the results and to reduce computation (Campen \& Bot 2003), the simulations were run at three different grid resolutions, namely with $712,029,852,550$ and 1,192,514 elements, respectively. 


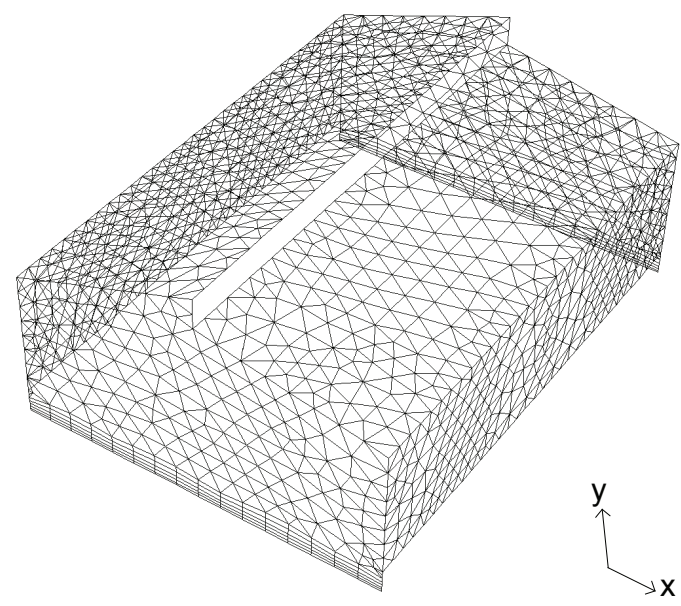

(a)

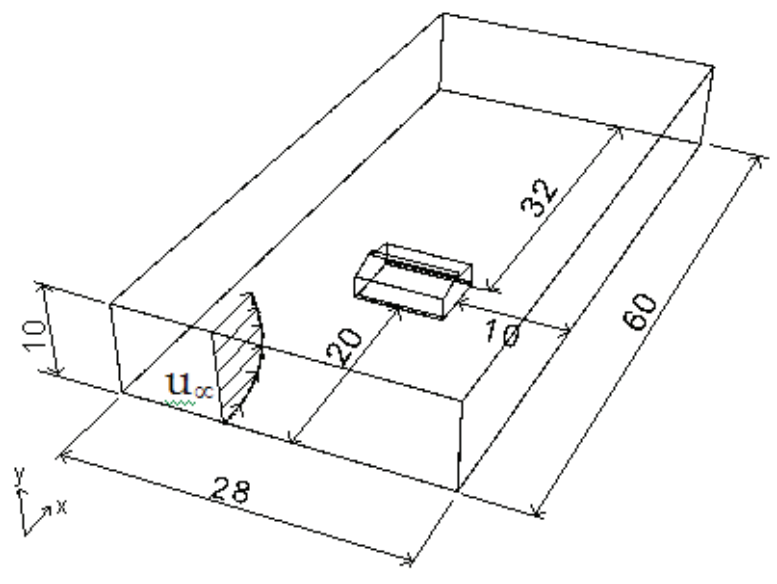

(b)

Figure 4-Three dimensional, unstructured mesh of the greenhouse domain (a) and the computational domain size showing the wind $\boldsymbol{u}_{\boldsymbol{\mu}}$. Dimensions are in $\mathbf{m}(\mathrm{b})$

Şekil 4 - $a$, ̈̈ç boyutlu imal edilmemiş sera alanı; b, rüzgarı gösteren hesaplanmış alan; boyutlar m'dir

\subsection{Boundary conditions}

The inlet flow boundary creates an atmospheric wind velocity profile. The velocity boundary condition in a prevailing windward is assumed to be incompressible, with a logarithmic relationship between height and wind speed (Hoxey \& Richards 1992; Hargreaves \& Wright 2007; Blocken et al 2007). The inlet of the velocity profile was defined by Richards \& Hoxey (1993). According to the outlet boundary-specified conditions, the relative value of the static pressure with a normal gradient is zero, and the other variable is zero: i.e., $\partial / \partial x=0$. A non-slip wall is used for the solid regions (the ground and greenhouse walls), based on a classical logarithmic wall function. On the top and sides of the computational domain, symmetry-type boundary conditions are used to determine both the zero normal velocity and the gradients of all variables at the symmetry plane (Khaoua et al 2006). The inlet boundary of the atmospheric wind velocity profile at $6 \mathrm{~m}$ is defined by the initial velocity of $0.5,1.5$ and $2 \mathrm{~m} \mathrm{~s}^{-1}$ at an average ambient temperature of $305 \mathrm{~K}$. The inside boundary conditions for the greenhouse are based on the maximum temperature $(\Delta T=8 \mathrm{~K})$ produced by outside solar radiation of $800 \mathrm{~W} \mathrm{~m}^{-2}$. These values were selected from the measurement data and were based on the maximum average of the database for the weather conditions and climate of Thailand (Thai Meteorological Department 2005). At the roof of the greenhouse, the heat flux of the greenhouse roof boundary is $112 \mathrm{~W} \mathrm{~m}^{-2}$ (Tuntiwaranruk et al 2006). The greenhouse walls and the ground floor were defined as the heat transfer coefficients boundary (Roy et al 2002). The summary of the values of the boundary details are used for the simulation, as shown in Table 1.

\section{Results and Discussion}

\subsection{Validation of $C F D$ results against experimental results}

Figure 5 shows the ventilation rate comparison between the measurement data and the simulation results when run with three different grid resolutions. The study result shows that sidewall vents at $0.4 \mathrm{~m}$ from ground level, or $15 \%$ of the height of the sidewalls, with an external wind speed variation of $0.5-2.0 \mathrm{~m} \mathrm{~s}^{-1}$ and a slightly sloping roof result in the coarse grid having an 
Table 1-Parameter values of boundary conditions used for the simulations

Çizelge 1-Simülasyonda kullanılan sınır koşullarının parametreleri

\begin{tabular}{lll}
\hline Parameters & Numerical value & Dimensions \\
\hline Outside air temperature & 305 & $\mathrm{~K}$ \\
Outside wind speeds $\left(u_{\mu}\right)$ & $0.5,1.5,2$ & $\mathrm{~m} \mathrm{~s}^{-1}$ \\
Outside soil surface temperature & 305 & $\mathrm{~K}$ \\
Heat flux of greenhouse roof & 112 & $\mathrm{~W} \mathrm{~m}^{-2}$ \\
Heat transfer coefficient of outside greenhouse wall & $7.2+3.84 \cdot u \propto$ & $\mathrm{W} \mathrm{m}^{-2} \mathrm{~K}$ \\
Heat transfer coefficient of inside greenhouse wall & 7.2 & $\mathrm{~W} \mathrm{~m}^{-2} \mathrm{~K}$ \\
Heat transfer coefficient of greenhouse floor & $5.2 \times \Delta T^{0.33}$ & $\mathrm{~W} \mathrm{~m}^{-2} \mathrm{~K}$ \\
\hline
\end{tabular}

*, $\Delta T$, internal and external temperatures differences $(\mathrm{K})$

error prediction of $<15 \%$. When comparing the grid to the calculation results in terms of $\mathrm{Gr} \mathrm{Re}^{-2}$, together with the measurement data regarding the vertical axis in the middle of the greenhouse as shown in Figure 6, the research found that the simulation results have good agreement with differences of \pm 0.11 . Considering the case of roof angle variations in the SSG greenhouse, the computational grid was given by the low resolution variants, between 729.170-731.116 elements, which will be used when analysing ventilation behaviour in the next section.

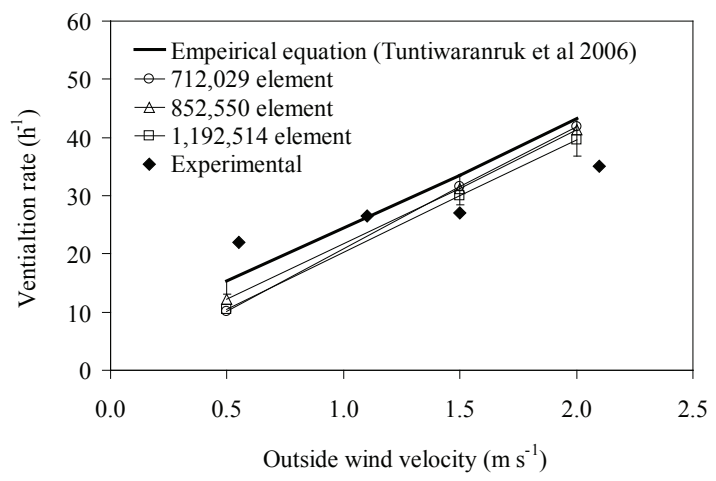

Figure 5- Comparison between the experimental findings presented by Tuntiwaranruk et al (2006) and experimental results, findings obtained by using three different grid resolutions, and the opposition of the ventilation rate as a function of the outside wind speed Şekil 5- Tuntiwaranruk et al (2006) tarafindan bulunan deneysel verilerle üç farklı grid çözünürlük ve dış rüzgar hizının fonksiyonu olarak vantilasyon hizina bağlı olarak bulunan sonuçların karşılaştırılması

\subsection{The ventilation problems of a slightly sloping} roof in the $S S G$

Figure 6 shows the investigated ventilation system formation in terms of $\mathrm{Gr} \mathrm{Re}^{-2}$, which considers the vertical line at the center of the greenhouse to be at a height of 0.5 to $2.5 \mathrm{~m}$ from ground level. The calculation results of $\mathrm{Gr} R \mathrm{Re}^{-2}$ shows a range of 0.30.8 , with the dominant ventilation system in the greenhouse being wind driven (Mills 1999; Wang \& Boulard 2000; Roy et al 2002). As shown in Figure $7 \mathrm{a}$, the wind-induced air wake reduced hot air at a

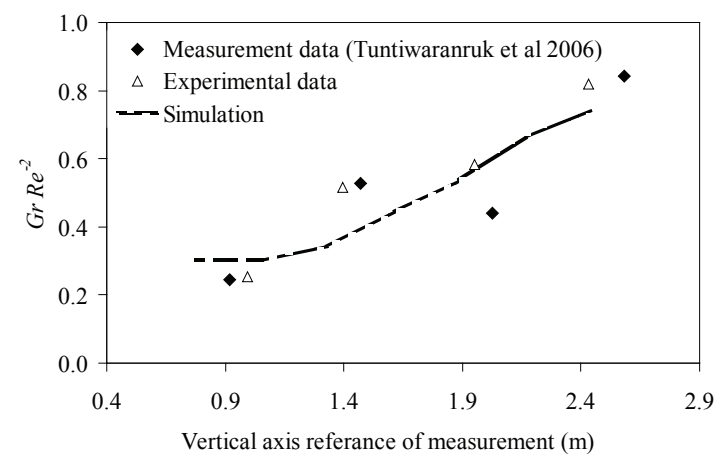

Figure 6-Comparison between the experimental findings presented by Tuntiwaranruk et al (2006) and experimental results, simulation results using coarse grid resolution on $G r \boldsymbol{R e}^{-2}$ relative to the middle distance of the SSG-greenhouse

Şekil 6-Tuntiwaranruk et al (2006) tarafindan bulunan deneysel verilerle çatının orta açıklı̆̆ına gore Gr Re-2 deki kaba grid çözünürlü̆̈ün simülasyonu sonuçlarının karşılaş̧tırılması 
height of $<0.7 \mathrm{~m}$ from the ground. Internal hot air remains at a height of $>0.7 \mathrm{~m}$ when $G r R^{-2} \geq 1$, considering that the vertical line is $>2.5 \mathrm{~m}$ in height. Thus, the ventilation system trend observed in the above criteria is free convection, or thermal driven ventilation, which influences the heat storage under the roof.

Figure 7 shows the air flow pattern and air temperature distribution of the greenhouse with an external wind speed of $1.6 \mathrm{~m} \mathrm{~s}^{-1}$. It was found that the external wind speed through a ventilation opening at a height of $0.4 \mathrm{~m}$ from ground level generated the internal air wake. This effect induced the ventilation to move to the roof vent and to the other sidewalls. However, when the internal air pressure is lower, the air ventilation via the roof vent will be obstructed by the external wind speed, as backward wind on the roof top will be caused by high pressure. When the ventilation performance of the roof vent decreased, it affected the heat storage under the greenhouse roof, as shown in Figure $7 \mathrm{~b}$. The average air temperature at a height of $1.5 \mathrm{~m}$ from ground level is $308 \mathrm{~K}$, while the air temperature difference is $6-8 \mathrm{~K}$.

Greenhouses should have a temperature close to the external ambient temperature. The simulation results describing the temperature distribution in the
SSG, as shown in Figure 7b, show that the internal air temperature at a height of $0.4 \mathrm{~m}$ from the ground is much higher than is the ambient temperature, by an average of 2-3 K, when the external wind speed at the ventilation opening falls within the range of 1.6-1.8 $\mathrm{m} \mathrm{s}^{-1}$. In this case, the average value of the internal wind speed inside the greenhouse is $0.638 £ u_{\mathrm{i}} \leq 1.0 \mathrm{~m}$ $\mathrm{s}^{-1}$, based on the report presented by Kalma $\&$ Kuiper (1999). In addition, the definition of the internal wind speeds in order to maintain favorable conditions for crop growth is within the range of $0.1-0.6 \mathrm{~m} \mathrm{~s}^{-1}$ (Robert \& John 1989). In Figure 7, considering a wind speed of $0.6 \mathrm{~m} \mathrm{~s}^{-1}$, the internal air temperature is higher than is the ambient temperature of $5 \mathrm{~K}$ as a result of the inefficiency of the ventilation. As a result of natural ventilation through the roof and the sidewall vents in tropical climatic conditions with low external wind speeds of less than $2 \mathrm{~m} \mathrm{~s}^{-1}$, and with sidewall vents at a height of $0.4 \mathrm{~m}$ from the ground, this serves to control the internal wind speed (Kalma \& Kuiper 1999; Robert \& John 1989). However, it fails to reduce hot air, because the internal air temperature is higher than is the external air temperature. Solutions based on various angles of roof pitch were studied in order to reduce the internal air temperature at a height of $<2.5 \mathrm{~m}$ from the ground.

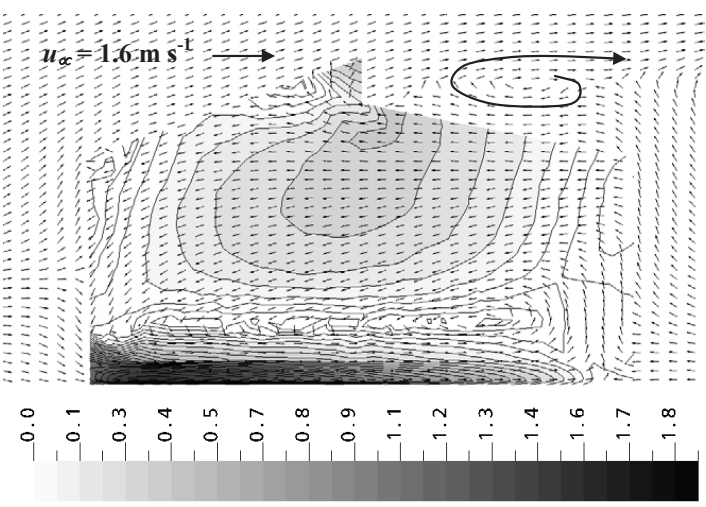

Velocity, $\mathrm{m} \mathrm{s}^{-1}$

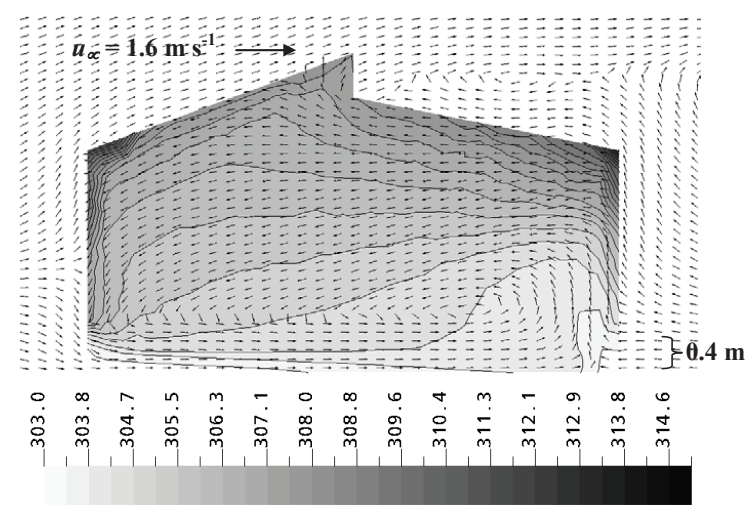

Temperature, $\mathrm{K}$

(a)

(b)

Figure 7- Flow pattern (a) and temperature distributions (b) of air inside a SSG-greenhouse, with side openings of $15 \%$, or $0.4 \mathrm{~m}$ from ground level, with an outside wind velocity of $1.6 \mathrm{~m} \mathrm{~s}^{-1}$ at wind a direction of $0^{\circ}$

Şekil 7- Yan açıklık\% 15 ya da yer seviyesinden $0.4 \mathrm{~m}$ yukarıda; $0^{\circ}$ rüzgar açısında dış rüzgar hızı $1.6 \mathrm{~m} \mathrm{~s} \mathrm{~s}^{-1}$ koşullarında; a, akış paterni; b, sıcaklık dă̆ılımı 


\subsection{Ventilation performance of variations of the angle of the roof}

The heat storage problem that occurred in the SSG with a slightly sloping roof was investigated in the roof angle variations where reducing the internal hot air at a height of $<2.5 \mathrm{~m}$ under the gable roof was considered, which had previously been storing heat before the ventilation of hot air via the roof vent. Figure 8 shows the calculation results of the ventilation rate according to the variation in the angle of the roof in terms of the average ventilation function, $G(\alpha)$, compared with the external wind speed. In cases where the wind speed was $<1.5 \mathrm{~m}$ $\mathrm{s}^{-1}$, the variation of the angle of the roof influenced the performance of the ventilation. When the wind speed criteria was $>1.5 \mathrm{~m} \mathrm{~s}^{-1}$, the ventilation system was predominately wind-influenced and variation in the angle of the roof was unimportant. At wind speeds of $<1.5 \mathrm{~m} \mathrm{~s}^{-1}$, the roof incline reduced the drag force by thermally driven forces, as shown in Figure 9, which depicts the flow pattern and vector field of the internal air. It was found that, with a roof angle of $30^{\circ}$ and $42^{\circ}$ (Figure 9b-9c), the speed of air movement under the roof slope was higher than in the centre of the greenhouse. When compared to the angle roof of $15^{\circ}$, the research showed that most of the air wake expanded inside the greenhouse and the internal air attempted to outflow from the roof vent. Thus, a roof angle of $15^{\circ}$ shows decreased $G$ $(\alpha)$ when the external wind speed is less than $1.5 \mathrm{~m}$ $\mathrm{s}^{-1}$. In addition to a wind speed of $>1.5 \mathrm{~m} \mathrm{~s}^{-1}$, Brugger et al (2005) also studied ventilation in a Parral style greenhouse with an external wind speed of $>2 \mathrm{~m}$ $\mathrm{s}^{-1}$, whereby increasing the roof angle above $27^{\circ}$ provided a minimal, additional air exchange rate.

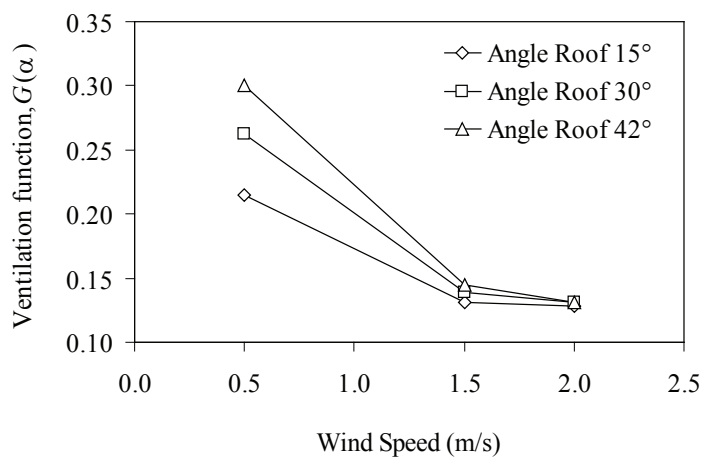

Figure 8 - Comparison of the ventilation performance defined by the ventilation function, $G(\alpha)$ representing the variations of roof angles at external wind speeds of $0.5,1.5$ and $2.0 \mathrm{~m} \mathrm{~s}^{-1}$

Şekil 8 - Farklı çatı açılarında rüzgar hızı ve vantilasyon performansı arasındaki ilişki

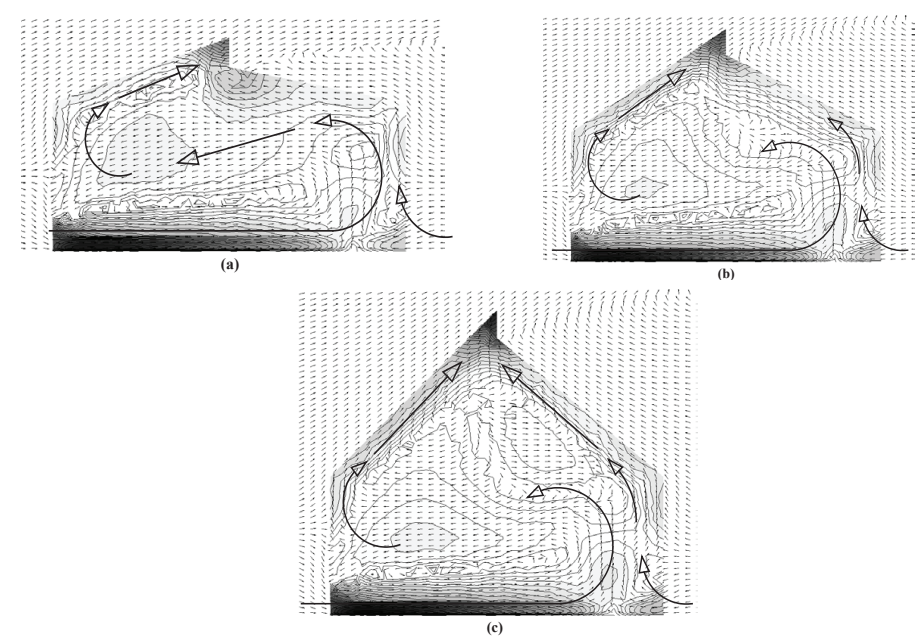

Figure 9 - Comparison of the velocity vector inside the greenhouse when the wind speed is $0.5 \mathrm{~m} \mathrm{~s}^{-1}$ for a roof angle of (a) $15^{\circ}$, (b) $30^{\circ}$ and (c) $42^{\circ}$

Şekil 9 - Çatı açılarının $a, 15^{\circ} ; b, 30^{\circ}$ ve $c, 42^{\circ}$ çatı açılarında ve rüzgar hızının $0.5 \mathrm{~m} \mathrm{~s}^{-1}$ olduğu koşulda sera içindeki hız vektörü 
Investigation of the ventilation function can be considered in terms of ventilation resistance or ventilation requirements. For example, with a roof angle of $42^{\circ}$ with an external wind speed of $0.5 \mathrm{~m} \mathrm{~s}^{-1}$, the ventilation resistance or ventilation requirement is 0.3 of air inlet volume. In cases where the wind speed is $2 \mathrm{~m} \mathrm{~s}^{-1}$, the ventilation resistance or ventilation requirement will be lower than 0.15 of the air inlet volume. Thus, increasing the external air wind speed meant that the ventilation resistance, or ventilation requirement, was decreased. Hsin $\mathrm{Yu}$ et al (2002) presented the opening effectiveness of livestock buildings by varying the angle of the roof at various external wind speeds of $1.5-4.5 \mathrm{~m} \mathrm{~s}^{-1}$. The result shows that the effectiveness of the opening was less when the roof slope was $>30^{\circ}$. The wind speed makes ventilation dominant. All the above investigation shows that the ventilation performance depends on the external wind-influence, while the angle of the roof configuration supports the reduction of the heat convection under the roof.

Considering the air temperature in terms of temperature function, $\left(\Delta T / T_{\mathrm{o}}\right)$ as shown in Figure 10 , the air temperature in the greenhouses with various roof angles are expressed as a function of the external wind speed within a range of 0.5 $2 \mathrm{~m} \mathrm{~s}^{-1}$. It was found that the decrease in the air temperature depended on the external wind speed. When comparing the roof angles of $30^{\circ}, 42^{\circ}$ and $15^{\circ}$, it was found that the average of the internal air temperature rose by up to $10-20 \%$ in criteria where the roof slope was $15^{\circ}$. This shows that the influence of a low slope causes an increase in air temperature. In other words, the canopy under the slightly sloping roof is not a heat storage zone and a wake of hot air transfers into the center of the greenhouse.

Furthermore, Figure 10 shows that there is no decrease in the air temperature inside the greenhouse, with an increase in the roof angle to a value of more than $30^{\circ}$. Figure 11 shows the simulation results on the internal air temperature distribution associated with each variation of the roof angle. Regarding the external wind speed of $0.5 \mathrm{~m} \mathrm{~s}^{-1}$ combined with a roof angle of $42^{\circ}$ (Figure 11c), it was found that, when the inclination angle of the roof is increased, the space

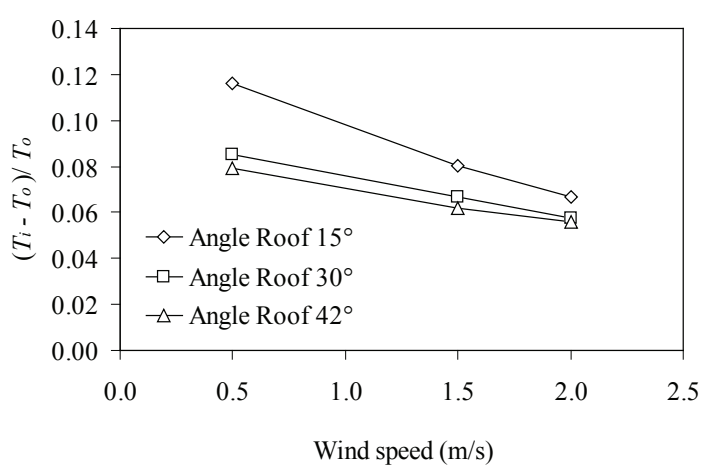

Figure 10- Comparison of roof slopes on the temperature function $\left(\Delta T / T_{o}\right)$, relative to the wind speed.

Şekil 10- Rüzgar hızına bağlı olarak sıcaklık ve çatı eğimi arasındaki ilişki

(point b) close to the gable roof becomes narrower. The performance of the internal air temperature and air ventilation is closer to the angle of the roof when it is $30^{\circ}$. In addition, heat storage effects occurred inside the greenhouse at a height of $>2.5 \mathrm{~m}$ from the ground. This effect is generated by the decrease in the internal air temperature, which equals $\Delta \mathrm{T}=1-2 \mathrm{~K}$ at a height of $<2.5 \mathrm{~m}$ from the ground. By contrast, at a roof angle of $15^{\circ}$ and at a height of $<2.5 \mathrm{~m}$, the air temperature was increased. Based on the internal air temperatures associated with each variation in the angle of the roof, the air temperature difference $\left(\mathrm{T}_{\mathrm{i}}-\mathrm{T}_{\mathrm{o}}\right)$ is correlated with the external wind speed function $\left(\mathrm{u}_{\mathrm{u}}\right)$. As shown in Table 2, the variation in the angle of the roof by $10^{\circ}-15^{\circ}$ can reduce the internal air temperature $\Delta \mathrm{T} \cong 1-1.5 \mathrm{~K}$, based on the average air temperature data for each case study.

Because heat storage causes the internal air temperature to rise, heat storage influences the ventilation system inside the greenhouse. Figure 12 presents the ventilation system results as guidelines for reducing the air temperature. This figure expressed the ventilation system by the angle of roof variation in terms of $\mathrm{Gr} R e^{-2}$ as a function of the external wind speed. The reference criterion for this term is to consider the ventilation system inside the greenhouse at a height of $2.5 \mathrm{~m}$ from the ground. 

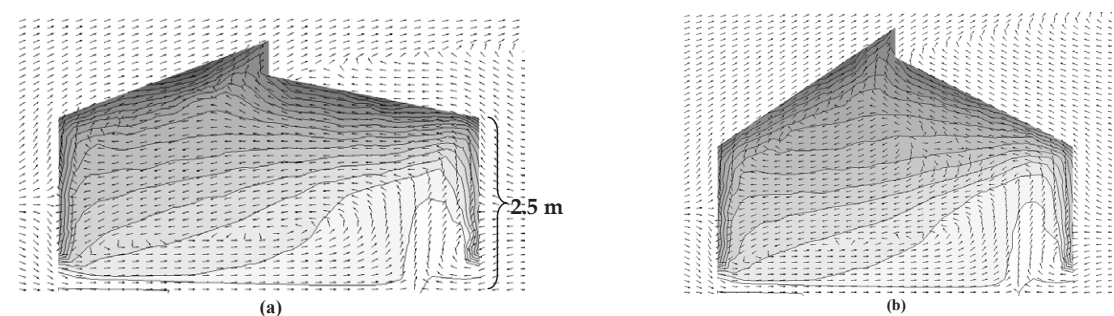

(a)

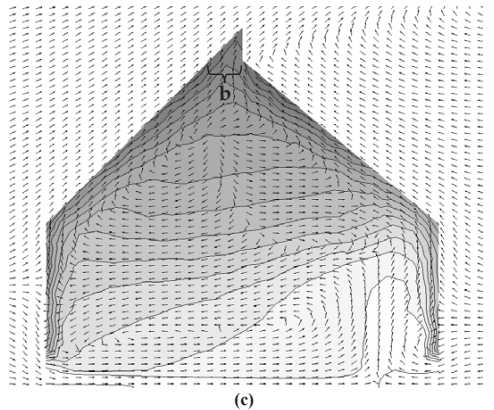

Figure 11- Comparison of the temperature distribution inside the greenhouse when the wind speed is $0.5 \mathrm{~m}$ $\mathrm{s}^{-1}$, with a roof angle of (a) $15^{\circ}$, (b) $30^{\circ}$ and (c) $42^{\circ}$

Şekil 11-Rüzgar hızının $0.5 \mathrm{~m} \mathrm{~s}^{-1}$ ve çatı açılarının a, $15^{\circ}$; b, $30^{\circ}$ ve c, $42^{\circ}$ olduğu koşulda sera içindeki sıcaklık dağ̊lımınin karşılaş̧tırılması

Table 2- Linear regression equations for the regression of temperature difference $\Delta \boldsymbol{T}$ at wind speed $\boldsymbol{u}_{\propto}$ Çizelge 2- Rüzgar hızı $u_{\propto}$ ve $\Delta T$ sıcaklık farkında doğrusal regresyon eşitlikleri

\begin{tabular}{lll}
\hline Angle roof & Regression equation & $R^{2}$ \\
\hline $15^{\circ}$ & $\Delta T=4.168-1.052 u_{\propto}$ & 0.998 \\
$30^{\circ}$ & $\Delta T=2.969-0.574 u_{\propto}$ & 0.999 \\
$42^{\circ}$ & $\Delta T=2.730-0.494 u_{\propto}$ & 0.994 \\
\hline
\end{tabular}

$R^{2}$ is the coefficient of determination

The study results indicate that, at an external wind speed of $0.5 \mathrm{~m} \mathrm{~s}^{-1}$ and a value of $G r R^{-2}$ of $<1$, based on a roof slope angle of $30^{\circ}$ and $42^{\circ}$, the ventilation system was predominately wind-induced. When $\mathrm{Gr}$ $R e^{-2}=1$, with an angle roof of $15^{\circ}$, the ventilation system inside the greenhouse is dominated by mixed convection (Mills 1999). Assuming an external wind speed of $<0.5 \mathrm{~m} \mathrm{~s}^{-1}$, the value of $G r R^{-2}$ increased to $G r R e^{-2}>1$, and the ventilation system inside the greenhouse, having mixed convection, would be transformed into free convection or thermal driven ventilation. This causes the air temperature inside the greenhouse to be higher. In addition to these studies, those of Papadakis et al (1992) proposed the criteria for considering the ventilation system inside the greenhouse. When $\mathrm{Gr} \operatorname{Re}^{-2}<1$, the ventilation system is wind-induced and, when $0.1<G r R^{-2}<16$, the ventilation system is mixed convection. Figure 12 shows the ventilation system as mixed convection with an external wind speed of $<1 \mathrm{~m} \mathrm{~s}^{-1}$, and the ventilation system in wind driven ventilation with an external wind speed of $>1.5 \mathrm{~m} \mathrm{~s}^{-1}$. At a wind speed of $0.5 \mathrm{~m} \mathrm{~s}^{-1}, G r \operatorname{Re}^{-2}$ at a range of $0.6<G r \operatorname{Re}^{-2}<1$ generated the ventilation system inside greenhouse as mixed convection. The greenhouse roof with an angle of $>15^{\circ}$ will be able to control the ventilation system inside the greenhouse by the wind-induced ventilation system, in order to avoid the ventilation 
systems with free or mixed convection in case of an external wind speed of $<1 \mathrm{~m} \mathrm{~s}^{-1}$.

\subsection{Wind loads on angle roof variations}

According to the incline of the angle, a roof will be damaged or dislodged by wind loads, and the simulation data of the external air flow will need to consider the effect of wind loads in terms of the wind pressure coefficient that is applied to the external surface of the roof configuration. Figure 13 shows the results of wind pressure coefficient simulation data on the X-axis in relation to the greenhouse span, $\mathrm{S}$, which is generated by the simulation data from the CFD technique. The data measurement is created by Oliveira \& Younis (2000), together with Gingera \& Holmes (2003), who studied the effect of wind loads applied to roofs of $27^{\circ}$ and $35^{\circ}$, respectively. After validation of the predicted results against the measured data, this research found the wind pressure coefficient at the reference roof angle to be an average of $15^{\circ}$ (wind loads applied to the roof side of the roof angle $20^{\circ}$ ) and $30^{\circ}$ (wind loads applied to the roof side of the roof angle of $33^{\circ}$ ). The simulation results are similar to those presented in the measurement data.

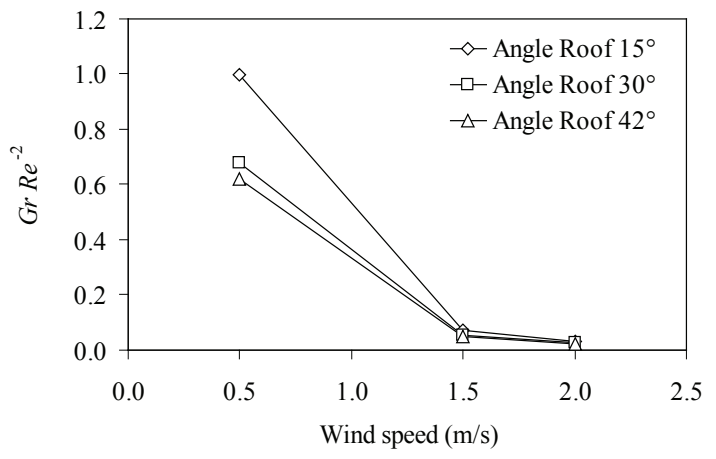

Figure 12- Comparison of the various roof slopes when the ventilation system is $2.5 \mathrm{~m}$ from the ground, with $\boldsymbol{G r} \boldsymbol{R} \boldsymbol{e}^{-2}$ as a functional wind speed

Şekil 12-Rüzgar hizının fonksiyonu olarak yerden 2.5 $m$ yukarldaki ventilasyon sisteminde $\mathrm{Gr} \mathrm{Re}^{-2}$ rüzgar hızı arasındaki iliş̧ki

Figure 13 considers the wind pressure coefficient, $C$, with angles of roof variations of $15^{\circ}, 30^{\circ}$ and $42^{\circ}$. The value of $C_{p}$ is windward, at a roof angle roof of $30^{\circ}$, which is close to zero. Meanwhile, if the roof slope is $15^{\circ}$ or $42^{\circ}$, the $C_{p}$ is -0.5 and 0.6 , respectively. The theory stated that the roof on the windward side has an angle of $30^{\circ}, d p / d x \cong 0$, and the air flow is transitional. When compared to a roof angle of $15^{\circ}, d p / d x<0$, this is called a favorable pressure gradient, while the gutter and the small inclination angle of the roof are induced as the wind velocity increases and the flow direction changes, which effects produce the wake of air on the roof. The effects created high pressure in the flow of the leeward wind applied to the greenhouse roof. In contrast to a roof slope of $42^{\circ}, d p / d x>0$, is called an adverse pressure gradient, where flow separation will not occur on the roof and the windward flow will create the high pressure on the roof side.

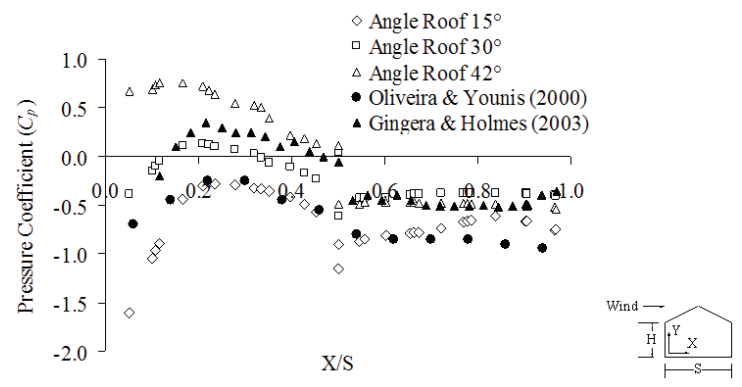

Figure 13- Predicted pressure coefficient of angle slope variations compared with measured pressure coefficients for greenhouse roof pitches produced by Oliveira \& Younis (2000) and Gingera \& Holmes (2003), for cases where the angle of the roof is $27^{\circ}$ and $35^{\circ}$, respectively

Şekil 13- Farklı çatı açılarında ve Oliveira \& Younis (2000) ile Gingera \& Holmes (2003) tarafindan üretilen çatı açıklıklarında basınç katsayıları

\subsection{The correlation between air ventilation and wind load on variations of the slope of the angle}

In this research, ventilation performance depends on the greenhouse geometry and vent opening. Thus, the roof angle and wind speed variation are used to determine the ventilation drag coefficient, $C_{d}$, at roof angles of $15^{\circ}, 30^{\circ}$ and $42^{\circ}$. The average values of $C_{d}$ are $0.641,0.650$ and 0.650 , respectively. In addition, the average value of $C_{d}$ is 0.636 , which is 
similar to the value stated by Parra et al (2004), who studied greenhouses with roof and side ventilation. However, the $C_{d}$ values for greenhouses with roof and side vents are within the range of 0.6-0.8, with an average value of $C_{d}$ at 0.66 (Roy et al 2002).

However, the roof angle variations influence the air temperature and ventilation performance and its failure in high gable roof shapes under wind loads. In consequence, considering the ventilation rate and the pressure coefficient of wind force applied to the external structure due to variations of the roof angles, which are investigated by the equation combination of the ventilation of Equation 2 with the pressure coefficient of Equation 5, the stack effect in Equation 2 is negligible. The result of the equation combination can be expressed by the following equation, $C_{d}^{2}=\left(C_{p} /\right.$ $\left.C_{w}\right)(2 \rho / \Delta P)\left(Q / A_{T}\right)^{2}$. Given the correlation between $C_{d}^{2}$ and $(2 \rho / \Delta P)\left(Q / A_{T}\right)^{2}$, as shown in Figure 14, it is found that the combination of the result of Equation 2 and 5 shows that the performance of a roof angle $15^{\circ}-30^{\circ}$ referred to the ventilation efficiency and loading efficiency of the wind force when applied to the structure on the roof side. A roof angle that is more than $30^{\circ}$ does not influence the increase of the air ventilation rate and the decrease of the air temperature. Therefore, a gable roof angle of $30^{\circ}$ is suitable for greenhouse building and construction.

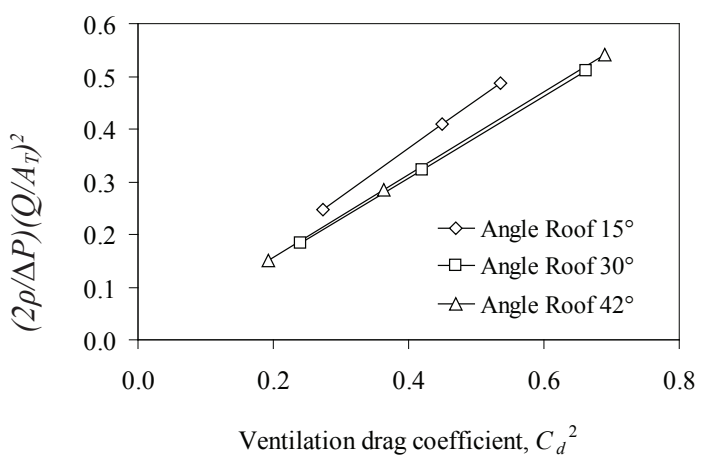

Figure 14- Effect of roof slope on ventilation performance and the wind pressure coefficient, presented in terms of the relationship between $C_{d}^{2}$ and $(2 \rho / \Delta P)\left(Q / A_{T}\right)^{2}$

Şekil 14- Farklı çatı açılarında vantilasyon sürüklenme katsayısı $\left(C_{d}^{2}\right)$ ve $(2 \rho / \Delta P)\left(Q / A_{T}\right)^{2}$ arasindaki ilişki

\section{Conclusions}

Investigation of the roof angle is conducted by considering the average variations in roof angles of $15^{\circ}, 30^{\circ}$ and $42^{\circ}$, in order to reduce the air temperature inside the greenhouse to that approximating the ambient temperature. The result showed that a roof angle of $<30^{\circ}$ is the maximum roof angle that contributes to the reduction of the internal air temperature, causing it to approach ambient temperature. There is a temperature difference between inside and outside the greenhouse, $\Delta T$ of $2 \mathrm{~K}$, when the ventilation system inside the greenhouse is $G r R e^{-2}<1$ at a height of $2.5 \mathrm{~m}$ from the ground, generated by predominately wind-induced ventilation.

Considering the ventilation performance as being relative to the wind pressure applied to the greenhouse roof, an equation combination of the ventilation rate equation and the pressure coefficient of the wind force when applied to the roof incline is needed. As a result of the equation, combined in terms of dimensions, the air temperature under the roof angle has an influence on the ventilation performance, which approaches ambient temperature. In conclusion, wind pressure applied to a greenhouse roof with a roof angle of $\cong 30^{\circ}$ is highly recommended for greenhouse building and construction.

\section{Acknowledgements}

The authors would like to express their sincere appreciation to the Energy Policy and Planning Office (EPPO) for the financial support of this research.

\section{References}

Albright L D (2002). Controlling Greenhouse Environments. Acta Horticulturae 578: 121-125

ASHRAE (1981). Fundamentals. ASHRAE Handbook, New York.

Ayata T (2009). Investigation of Building Height and Roof effect on the Air velocity and Pressure distribution Around the Detached Houses in Turkey. Applied Thermal Engineering 29(8-9): 1752-1758 
Baeza E, Pérez-Parra J, Montero J, Bailey J, López C \& Gázquez C (2009). Analysis of the Role of Sidewall vents on Buoyancy-driven Natural ventilation in Parral-type Greenhouses with and without Insect Screens Using Computational Fluid Dynamics. Biosystems Engineering 104(1): 86-96

Bert Blocken, Ted Stathopoulos \& Jan Carmeliet (2007). CFD simulation of the Atmospheric boundary layer: Wall function Problems. Atmospheric Environment 41(2), 238-252

Bot G P A (1983). Greenhouse climate: From physical processes to a Dynamic model. PhD Thesis, Wageningen Agriculture University, Netherlands

Boulard T \& Baille A (1995). Modelling of Air exchange rate in a Greenhouse equipped with Continuous Roof Vents. Journal Agriculture Engineering Research 61: $37-48$

Brugger M, Montero J, Baezz E \& Pérez-Parra J (2005). Computational Fluid Dynamic Modelling to Improve to Design of the Spanish parral style Greenhouse. Acta Horticulturae 691: 425-432

Burnett J, Bojić M \& Yik F (2005). Wind-induced pressure at External Surfaces of a High-rise Residential Building in Hong Kong. Building and Environmental 40(6): 765-777

Campen J B \& Bot G P A (2003). Determination of Greenhouse-specific Aspects of Ventilation using Three-dimensional Computational Fluid Dynamics. Biosystems Engineering 84(1): 69-77

Connellan G J (2000). Australian Flower Conference: Greenhouse Design for a Healthy Cut Flower Crop, 2-6 August, Australia

Dayığlu A (2009). Determination of Heat and Mass Transfer Characteristics of Greenhouse Crops by Microclimatologic Model. Tarım Bilimleri Dergisi 15(1): $65-73$

Gingera J D \& Holmes J D (2003). Effect of Building Length on Wind loads on Low-rise Buildings with a Steep Roof Pitch. Journal of Wind Engineering \& Industrial Aerodynamics 91: 1377-1400

Hargreaves D M \& Wright N G (2007). On the use of the $\mathrm{k}$ - model in Commercial CFD Software to Model the Neutral Atmospheric Boundary Layer. Journal of Wind Engineering \& Industrial Aerodynamics 95(5): 355-369

Hoxey R P \& Richards P J (1992). Structure of the Atmospheric Boundary Layer Below $25 \mathrm{~m}$ and Implications to Wind loading on Low-rise
Buildings. Journal of Wind Engineering \& Industrial Aerodynamics 41(1-3): 317-327

Hsin Yu, Chiu-Hsiung Hou, Chung-Min Liao (2002). Scale Model Analysis of Opening Effectiveness for Wind-induced Natural Ventilation. Biosystems Engineering 82(2): 199-207

Kalma J D \& Kuiper F (1999). Transpiration and Growth of Phaseoulus vulgaris L. as affected by Wind speed. Mededelingen Landbouwhogeschool, Wageningen 66(8): $1-9$

Kittas C, Boulard T \& Papadakis G (1997). Natural ventilation of a Greenhouse with Ridge and Side openings: Sensitivity to Temperature and Wind effects. Transactions of the ASAE 40(2): 415-425

Krasaechai A (1999). Protective Structure for Flower Production of Royal Project Foundation. In: International seminar on Protective Structures for Improved crop Production. 12-17 April, Korea, pp. $\mathrm{X} 1-\mathrm{X} 18$

Mills A F (1999). Basic Heat and Mass Transfer. 2 ed, Prentice Hall Inc, New Jersey

Mistriotis A \& Briassoulis D (2002). Numerical estimation of the Internal and External Aerodynamic Coefficients of a Tunnel Greenhouse Structure with Openings. Computers and Electronics in Agriculture 34: 191-205

Oliveira P J \& Younis B A (2000). On the Prediction of Turbulent flows around Full-scale Buildings. Journal of Wind Engineering \& Industrial Aerodynamics 86: 203-220

Ould Khaoua S A, Bournet P E, Migeon C, Boulard T \& Chassériaux G (2006). Analysis of Greenhouse Ventilation Efficiency based on Computational Fluid Dynamics. Biosystems Engineering 95(1): 83-98

Papadakis G, Frangoudakis A \& Kyritsis S (1992). Mixed, forced and free convection heat transfer at the greenhouse cover. Journal of Agriculture Engineering Research 51: 191-205

Pérez-Parra J, Baeza E, Montero J I \& Bailey B J (2004). Natural ventilation of Parral Greenhouses. Biosystems Engineering 87(3): 355-366

Richards P J \& Hoxey R P (1992). Computational and Wind tunnel Modelling of Mean Wind loads on the Silsoe structures Building. Journal of Wind Engineering \& Industrial Aerodynamics 43(1-3): 1641-1652 
Robert A \& John W (1989). Greenhouse Engineering. Second edition, Northeast Regional Agriculture Engineering Service, University of Wisconsin, Madison

Roy J C, Boulard T, Kittas C \& Wang S (2002). Convective and Ventilation Transfers in Greenhouses Part 1: the Greenhouse considered as a Perfectly Stirred Tank. Biosystems Engineering 83(1): 1-20

Sethi V P \& Sharma S K (2007). Survey of cooling technologies for worldwide agricultural greenhouse applications. Solar Energy 81(12): 1447-1459
Sethi V P (2009). On the Selection of Shape and Orientation of a Greenhouse: Thermal modeling and Experimental validation. Solar Energy 83(1): 21-38

Thai Meteorological Department. Document climatologically data for the period 2000-2004.

Tuntiwaranuruk U, Thepa S, Tia S \& Bhumiratana, S (2006). Comparison Between Measured and Predicted Ventilation Rates in a Naturally Ventilated Greenhouse. Acta Horticulturae 699: 439-448

Wang S \& Boulard T (2000). Predicting the Microclimate in a Naturally Ventilated Plastic House in a Mediterranean Climate. Journal of Agriculture Engineering Research 75(1): 27-38 